International Association for the Psychology of Language Learning (IAPLL)

Journal for the Psychology of Language Learning

ISSN: 2642-7001. http://www.iapll.com/journal

Issue 1, June 2019, pp. 83-105

\title{
Methodological Diversity in Emotions Research: Reflexivity and Identities
}

Masuko Miyahara, International Christian University, Tokyo, Japan

\begin{abstract}
In this first issue of The Journal for the Psychology of Language Learning, this paper discusses some of methodological issues surrounding research methodology on emotions in the field of applied linguistics and language learning research. The aim of this paper is to develop a basic understanding and awareness of the challenges and issues involved in conducting research on emotions by bringing the notion of researcher's reflexivity to the forefront. Studies on researcher's reflexivity in any empirical research is nothing new, but how it is actually incorporated and manifested in the research process is a fairly neglected matter. The purpose of this paper is thus to pursue this matter by revisiting one of author's previous research that explores emotions in conjunction with its related and intertwining factors such as identity, L2 self, positionality and learners' language learning experiences.
\end{abstract}

Keywords: emotions, identity, narrative studies, reflexivity

Until quite recently, the study of emotions in applied linguistics and language learning research has received relatively little attention (Dewaele, 2015; MacIntyre 2002). Several reasons can be attributed to this phenomena, such as the supposedly highly subjective, fuzzy, and fluid nature of the concept of emotions. The Cartesian view of emphasizing cognition over affect has historically left emotions at the peripheries of the research literature.

However, with the emergence of humanistic approaches in education (Lei, 2007) and the understanding that emotions are "an integral part of cognition" (Swain, 2013, p. 195) in the field of applied linguistics research has generated the present sentiment that emphasizes the inseparable nature of cognition and emotions. As a result, there has been a surge of interest in the affective domain of teaching and learning that includes emotions. The general understanding of the area of emotions in current applied linguistics, SLA, and psychology is thus based on the idea that human cognition and emotions are connected and continuously 
interact and influence each other (e.g. Forgas, 2000; Schunk, D. H., Pintrich, P. R., \& Meece, J. L. (2008); Swain, 2013).

In the area of applied linguistics and SLA, there has been a particular focus on negative emotions as exemplified in the all-to-famous work of Horwitz (2001) on learners' anxiety in language learning. However, as studies on emotions expand, the focus on the simplistic binary division between positive and negative emotions is replaced with a more holistic view where positive and negative emotions each have a role to play: "the positivebroadening and negative-narrowing power of emotions" as shown in the works of MacIntyre and Gregersen (2012, p. 197) is one such example. The positive psychology movement (Fredrickson, 2001) also appears to have contributed in advancing the understanding of positive and negative emotions (Dewaele $\& \mathrm{Li}$, 2018). Furthermore, stemming mainly from the field of education, studies on emotions have shifted by taking on another dimension: one that focuses on teachers' emotions as well as those of learners. This is illustrated by increasing numbers of publications in academic journals (e.g. Dewaele, Mercer, \& Gkonou, 2018) and a recent book such as the edited volume entitled 'Emotions in Second Language Teaching: Theory, Research and Teacher Education' by Martinez Agudo (2018). One can also observe the trend of the foci on emotions in conference themes such as the second Psychology in Language Learning conference in 2014 and JALT (Japan Association of Language Teachers) Conference in 2017.

Thus, at the dawn of the era of the 'emotional turn', empirical research related to emotions in the context of instructed language learning is ever broadening and expanding both thematically and methodologically. The special issue of Studies in Second Language Learning and Teaching (2018) that features emotion serves as an excellent example that illustrates this point. Although studies are framed under the big umbrella term of emotions, not only do the ways in which emotions are conceptualized vary, but they differ in how the research questions are framed, and how the research methodology and methods are employed in the research. In addition, depending on the research inquiry, a variety of research methodologies and methods are adopted: some take a quantitative approach (e.g. Csillagh, 2015), others employ a more qualitative oriented approach (e.g. Costa, 2015), while, still others adopt the mixed methods line of inquiry (e.g. Gkonou \& Miller, 2017). At this present time when there appears to be an emerging wave of interest towards studies on emotions in SLA, I therefore believe it is necessary for researchers to stop and contemplate on the methodological issues involved in the research before attempting to move further. This could be especially relevant since both the researchers and the subjects are often human 
participants, the "messiest part of real-world research" (McKinley \& Rose, 2017, p. 6). The main imminent question is: just how do we go about researching something as complex and evasive as emotions in language learning?

The aim of this paper is thus to develop a basic understanding and awareness of the debates and issues involved in conducting research on emotions in the field of language learning. The purpose, however, is not to provide definite answers, but to identify and delineate the challenges that researchers need to examine in pursuing their studies. I attempt to do this by revisiting one of my previous qualitative research studies on this subject that explores emotions in conjunction with its related and intertwining factors such as identity, L2 self, positionality, and learners' learning experience. In particular, the notion of reflexivity is bought to the forefront as a crucial element in conducting studies on emotions. Obviously, studies on researchers' reflexivity in any empirical research is nothing new, but how it is actually incorporated and manifested in the research process is still underexplored. This paper argues that reflexivity is important for any empirical research, but it is more so relevant for studies in emotions.

This article begins by presenting an overview of the concept of emotions in language learning research, and how it is conceptualized in the sample study. Second, it will present a brief description of the notion of reflexivity as well as the methodological approach of this sample study, namely, narrative inquiry. I will then show how reflexivity is endorsed by consciously attempting to incorporate the notion in my study. At this present time when there is a surge of diversity and plurality both thematically and methodologically in emotions research, the paper concludes by arguing the importance for serious contemplation on the methodological issues. In this first issue of the Journal for the Psychology of Language Learning, I think it is most timely to bring the fundamental concerns surrounding research methodology to the forefront.

\section{Situating the Scene}

\section{Emotions in current language learning research}

To date, researchers in the field of SLA and language learning research have not failed to underscore the significance of the role that affect, including emotions, play in an individual's language learning experience and learning outcomes (Arnold, 1999; Garret \& Young, 2009; Gass \& Selinker, 2008; Horwitz, 2001). It is encouraging to see how the recent focus on the relationship between language, culture, and identity has increased such awareness of the role of affective factors, in which emotions are considered to play a major 
role in the learners' learning process (e.g. Kramsch 2003a, 2003b; Norton, 2013; Oxford, 2015; Piller \& Takahashi, 2006). The current prominent orientation to understanding emotions in the literature of language learning is to view the impact of emotions as socially constructed rather than to theorize it "as a psychological phenomenon that is located in the individual" (Zembylas, 2003, p. 216). Furthermore, Pavlenko (2005) argues the necessity to understand emotions as not only as inner states but also as relational processes by emphasizing their contextual nature: emotions are 'states, processes, and relationships (Pavlenko, 2005, p. xii). Thus, rather than singling out a particular emotional state as a possible variable in language learning, studies in emotions and language learning should take into account the complex interplay between the individual and social, and how its related components such as identity, self, motivation, etc. interact in a non-linear and holistic way (Dornyei, 2009; Mercer, 2011). In a similar vein, Benesch (2012) contends the social nature of emotions by regarding them as sticky objects; that is objects, ideas, and words that adhere to emotions. More recently, Prior (2016), following Sarbin (2001), also regards the emotions as social acts rather than a psychological construct or thing-like entity by making a distinction between emotion and what he terms emotionality. As Oxford claims "emotions are very social" (2015, p. 378).

\section{Emotions and identity}

As it is often cited in the literature, at the dawn of the 'social turn' in SLA (Block 2003), Bonny Norton's seminal work on identity of immigrant women in Canada revolutionized the notion of identity from a non-essentialist perspective (one based on the poststructuralist and constructivist theoretical viewpoints), where one's identity is understood as "how a person understands his or her relationship to the world, how that relationship is constructed across time and space" (Norton, 2013, p. 45). Here, identities are multiple, fluid and socially constructed (Block, 2007). Although implicitly stated, Norton's work is also an excellent example that demonstrates the role of emotions in identity construction and change. It argues that identity formation involves social forces such as power and agency that, in turn, influences the discourses of emotion and identity and vice versa. Similarly, Preece (2016) claims among other things, that learners' identities may be limited by their access to the social spaces where their identities are constructed, negotiated, and/or performed; their identities may be ascribed regardless of their preference, and could often position, or limit their rights to participation in the community their desire to operate in. The relevance of this for this paper is how emotions are intricately intertwined in this process. For instance, a 
university student on a summer study-abroad program might see their diminished 'self' (that tends to result in negative emotions of frustration) if they find themselves unable to participate freely in the discussion sessions with others; such an experience could lead students to be ascribed 'unwanted' identities (Miyahara, 2015).

\section{The use of narrative approach in emotion research and identity}

Researching emotions and identity involves a great deal of interpretative activity. The study of learners' (and for that matter teachers' as well) stories of their own experiences (and from their perspectives) is regarded as increasingly crucial (Clandinin \& Connelly, 2000). In the sample study in this paper, following Bruner (1990) and Clandinin and Connelly (2000), narratives are understood as fundamentally stories of 'experience'. People, both individually and socially, lead storied lives. Life is 'storied' in the way that people make sense of how they are (and others are) by interpreting their past in terms of their present lives and selves as well as their future lives and selves. Narratives are not only about people describing their past experiences, but also about how individuals understand those experiences, and how they ascribe meanings to those experiences (Clandinin, 2007). Mishler (1986) was the first to introduce to researchers the co-constructed nature of narratives by claiming that narratives produced in interview conversations is the result of the social interactions between speaker and listener. It thus follows that the meaning-making process is also a collaborative work.

The research questions in the study that I draw on in this paper required me to examine the experiences of my participants and to listen to their 'voices' to understand the complexities involved in forging their identities, and how the affective dimension might be implicated in the process. This called for a methodology that would allow me to be sensitive to the learners' accounts of their experiences. The narrative approach that focuses on the meaning making process of the participants, and where I could emphasize my role in coproducing the narratives appeared to be the best way to probe the inner complexities of my research participants.

\section{My interest in 'Reflexivity'}

More than we would like to admit, researchers are inevitably a part of the study as are the participants. How we take into account the effect of our presence on our research is a critical issue. Although discussions of incorporating researcher's reflexivity in the research process have increasingly been recognized as an important strategy (e.g., Finlay, 2012; Mann \& Walsh, 2017; Miyahara, 2017; Prior, 2016; Riessman, 2012; Roulston, 2010b), there 
appears to be no common understanding towards the notion of reflexivity, and the concept is often confused with reflection. In fact, one the reasons for my interest in the notion of 'reflection' emerged from this very question: what is the difference between 'reflection' and 'reflexivity'? In this paper, following Finlay (2012), I take reflection to mean 'thinking about' something after the event, and reflexivity, in contrast, involves an on-going selfawareness. That is, the former is a more of a descriptive process, whereas, the latter, refers to how you position yourself in the research context, and contemplate how one's own self could influence the actions one takes (i.e. self-awareness).

My interest in researcher reflexivity originated when I ventured out into publishing my book based on my doctoral work, Emerging Self-Identities and Emotion in Foreign Language Learning: A Narrative-Oriented Approach (Miyahara, 2015). As many scholars have done in the past, I, too, found myself turning the mirror on myself. Looking back at your own work is nothing new: autoethnography employed in anthropology or sociology is one example. Some scholars have criticized self-reflexivity because of its self-indulgent nature, but as Doyle (2013) posits, researchers' backgrounds and their emotions "must be thought about and analyzed, and the analysis used purposefully in the research process" (Doyle, 2013, p. 253). In my view, the important point is to always consider how the researcher's personal disclosure affects the narrative analysis, and how it contributes in understanding the phenomena at hand. Furthermore, self-reflexivity should not be just about the 'self', so to speak. Researchers should not merely discuss how their personal identities shaped their narrative projects, they should also consider how these identities intersect with the institutional, cultural, and socio-political context (Nagar \& Geiger, 2007). Extending one's reflexive gaze also helps to reinforce and further one's awareness of the self. Lastly, turning the mirror on my previous work revealed the situatedness (the academic, theoretical, political, social, etc.) of my interpretations. As it we naturally make assumptions, it is easier to identify our assumptions and 'blind spots' after some time has passed for stronger reflexivity. There is a temporal (and for that matter, spatial) element to reflexivity. For this very reason, many scholars have framed reflexivity in terms of its cyclical nature (Edge, 2011). Reflexivity illuminates a social phenomenon from many perspectives.

There are different ways of working with reflexivity. Some are connected to the coconstruction of data, others are interested in the positioning of the researcher, the participant, and their ever-changing relationship, and so forth. There also appears to be several dimensions to reflexivity (see details see Finaly's (2012) Five Lenses of Reflexivity), and for this paper, I focus on, in what Finlay (2012) would call contextual discursive and relational 
reflexivity. I aim to consider how researchers' and the participants' multiple and everchanging identities interact with the emotional aspects of the study at the analysis and representation stage. In what follows, I will now provide a brief sketch of myself before going on to offer contextual information of the research that I use as a sample to illustrate my point.

\section{The researcher}

As Canagarajah (1996, p. 324) notes any research "the subjectivity of the researchers-with their complex values, ideologies, and experiences-shapes the research activity and findings". However, a quick glance at published works in academia shows that many do not reveal information about themselves such as who they are, what positions they take in terms of the topics and the participants they examine, their values, ideologies, and experiences that bound to shape their research activity and findings. Obviously, it could be because of the stringent length requirements that is required by the editors. It could also be because it is impossible to include every aspect of yourself, but researchers need to be sufficiently self-aware as to know what areas are particularly relevant in the process of reporting. In this section, I will provide a brief account of aspects of my trajectory as a learner, a practitioner and a researcher that are pertinent to the shaping of this research project.

My interest in the studies of emotions in language learning stems from my experiences of interviewing my students who are studying English in the context of formal Japanese education. Having conducted numerous interviews for various research projects, at one point, I realized how learners' emotional disposition figured prominently in the interview extracts. This prompted me to further examine what was going on in their learning process. On the other hand, my interest in identity and language learning is largely rooted in my educational experiences in and out of Japan. I was born in Japan but spent most of my formative years overseas. After graduating from high school overseas, I returned to Japan to attend a college in Tokyo, which happens to be the research site of the sample study to follow. My educational experience as such is what some academics like Kanno (2003) would call the 'returnee' experience. One apt phrase that would characterize my language learning experiences over the years would be riding on a virtual roller coaster of ups and downs in language learning experiences and, henceforth, undergoing identity shifts and periods of mixed emotions towards myself as a language learner, and later, as a practitioner, and researcher. 


\section{Illustration: Reflexivity in Action}

\section{An overview of the sample study}

The narrative data for this article is drawn from a study that aimed to shed light on the understanding of process of L2-related identity construction and development among Japanese English at higher education in Japan (Miyahara, 2015). The particular feature of this study was its attempt to integrate socially and psychologically oriented perspectives on L2 identity formation by drawing on Dörnyei's L2 motivational self system (2009) as one of its theoretical frameworks. The research highlighted the instrumental agency of individuals in responding to and acting upon the social environment, and in developing, maintaining and/or reconstructing their desired identities as L2 users. It offered unique insights into the role of experiences, emotions, social and environmental affordances, and individuals' responses to these, in shaping their personal orientations to English and self-perceptions as English learner-users. The study shows the intricate analysis of past, present, and future dimensions of individuals' L2-related experiences and trajectories, and how these dimensions are intertwined through the process of narrative construction as participants relate their thoughts and emotions, and the researcher represents and interprets their stories (for details refer to Miyahara, 2015).

\section{The Research Site and the Participants}

The research site, a private university located in the suburbs of Tokyo, aims to build a global community where a diversity of people from various ethnic and religious backgrounds gathers together. This institution is also famous for its bilingual identity, and, in Japan, the graduates and alumni are regarded by the general public as being fluent and well-versed in the English-speaking language and culture. English is used on a daily basis as a means of communication not only in classes, but also in the daily lives of the students and faculty alike. The university has several college-wide courses that are required components for all students, and the English Language Program (ELP), that was later renamed 'English for Liberal Arts', ELA is one of them. Students, for whom English is a second language, must study English intensively for the first two years. The main focus of the program is designed to teach English for academic purposes with a focus on critical thinking. The curriculum is further complemented by a study abroad program referred to as the Study English Abroad (SEA) Program. The first- and second-year students are able to take part in the six-week program during the summer break at various universities located in the United States, the United Kingdom, Canada, New Zealand and Australia. In the end, a total of six students, all volunteers, going through their first year of their two-year English language curriculum 
participated in the study, but for the purpose of this paper, I will focus on one of them, Maki (a pseudonym).

Maki had a strong affinity for 'English', and considers it to index her identity. In terms of her past English language learning experiences, she started learning English from pre-school in the private sector of language schools in Tokyo upon her return from attending an international school in Bangladesh at the age of three. Although she had a sense of detachment towards English during primary and lower secondary education, she affirms a sense of membership of the broader world of English-users at the upper secondary and tertiary level, where she is able to develop a more positive affective orientation towards learning English.

\section{Analytical Process}

The method employed in this study is what is generally characterized as autobiographical narratives. I used a narrative interview strategy based on a series of semistructured questions to generate data in that the researcher did not have a list of questions but rather a range of topics to be covered (Block, 2008). The language in which talks were conducted is related to the jointly constructed nature of the interview process in narrative studies, and, thus, the participants were given choices, but none opted for English, including Maki, and thus, the language used in all interviews was Japanese. Five sets of interviews over a period of one year were conducted, each kept within an hour and a half, mainly for practical reasons. The narrative data was supplemented by other sources such as weekly journals, audio recordings or group discussions, and weekly self-reports during the six-week study abroad programs for those who participated in the SEA Program. The talks were audio-taped and transcribed in their entirety using a simplified transcription style. In terms of practicality, translations from Japanese to English were prepared for selected sections during the analysis. The transcripts were translated by the researcher and were reviewed and cross-checked by a bilingual colleague.

As the researcher, I also kept a journal composed of written entries that recorded my reflections, ideas, commentaries and memos throughout the research process in the attempt to make explicit my assumptions and values, and how they came about, and also to evaluate how they shaped the research process. A dialogue between myself and journal entries reinforced my belief that with any reflexive activity there is no escape from the 'self' (Roulston, 2010b). As Roulston posits: 'It [reflexivity] means turning the researcher lens back onto oneself to recognize and take responsibility for one's own situatedness, within the 
research and the effect that it may have on the setting and people being studied, questions begin asked, data being collected and its interpretation' (Roulston, 2010a, p. 220). In order to gain a better understanding of the role of self in the construction of knowledge, as noted earlier, it is significant to take into account the impact that the researchers' assumptions, beliefs, identities could have on their research. In practice, this is no easy task. Thus, to give myself some practical guidelines that address the concerns above, the four typologies outlined by Blaxter, Hughes and Tight (2001) were used as a strategy to assist entries in my journal (below):

-observational notes (describes events such as observation and interviews) -methodological notes (focus on the researcher/ participant's action and role) -theoretical notes (focus on articulating initial explanations from the data) -analytical memos (bring together inferences through review of other notes and literature and work towards patterns and themes).

Based on the above, I made comments about what occurred during the interview interactions with participants as well as thoughts, hunches, and questions that arose during the research process. I believe guidelines and models are not prescriptive rules for others to follow, but rather mediational tools for us to mindfully consider our actions and interactions with others. I also believe that it helps us to consciously sensitize ourselves to matters that we would normally not be able to discern or observe. The accounts of my reflections were thus used to analyze the talks. The aim was, as Hertz (1997) suggests 'presenting the author's self, whilst simultaneously writing the respondents' accounts and representing their selves'. Examples will be presented in the next section to illustrate how it was carried out in practice.

\section{Narrative Analysis and Researcher's Reflexivity}

\section{The analytical model: Incorporating researcher's reflexivity}

Before I present my account of how I 'wrote' myself in the narrative accounts to document my reactions, thoughts, and even emotions to acknowledge or critically (hopefully) engage with a range of possibilities of both the positions and identities of the researcher and the participants, and how emotions are implicated in the analysis, I would like to present a brief account of how the narratives were analyzed, interpreted, and presented.

The analytical approach taken in this study situates its philosophical approach to its analysis within the constructivist perspective on narratives (Gubrium \& Holstein, 2002), 
where the focus is more on the how questions as opposed to the what questions. The 'what' questions include 'what happened' and 'what were the experiences people had', while the 'how' questions include 'how do the participants position themselves while telling the stories?' and 'how does the interpersonal and/or social relationship shape the making of the stories?' (Frost, 2011). Obviously, any 'analytical model' will oversimplify the empirical practices of narrative analysis. I do not intend to prescribe or endorse a certain model, but the Six Step Analysis Model (refer to Miyahara (2015) for a detailed account of the model) represents my attempt to take into account the content (what) and form (how), as well as the context, which range from the micro-local to the macro-global was employed, the purpose in providing the analytical framework is to offer a guide to how the analysis was carried out, and also, to give transparency to the process of attempting to offer some insightful order to the multiple accounts of human experiences that my participants brought to the research site. The precise framework used will naturally depend on the enquiry, but in any narrative analysis, the reflexive involvement of the researcher at various stages of the analysis and representation of the data is inherent, and akin to what Mann (2011) refers to as the researcher's 'sensitivity'.

\section{Researcher's reflexivity in action}

As noted earlier, in line with Riessman (2008) and many leading scholars, narrative analysis is an iterative process: there is no specific moment when data analysis begins nor ends. For instance, researchers usually find that in the process of transcribing the oral data, they are already beginning to analyze the data (for this matter, analysis might even begin while conducting the interviews). Indeed, for that matter, my own processing did not always occur in a linear fashion as the Six Step Model (Miyahara, 2015) mentioned earlier might suggest, as the steps overlapped and quite often, I found myself moving back and forth in a cyclical manner.

Overall, the 'cyclical' nature of the analytical process, however, enabled me to see how and in what ways researcher's reflexivity could be manifested in the analytical process. 'Writing' yourself into your narrative study is easier said than done. As mentioned earlier, the process could simply mean to reveal your personal identities and thinking; on the other hand, it could also refer to how your identities intersect with the wider context of the institutional, material, and of the sociopolitical context. Sociologist such as Presser (2005) makes a distinction between strong and weak forms of reflexivity. 'Strong reflexivity' questions the institutional and political structure that contextualizes the research, whereas, the 'weak' 
version focuses more on the researcher's background, their thinking and emotions in the writings. In this paper, I have combined aspects of reflexivity from the weak version with some of socio-cultural dimension of the strong one to examine what the emotion lexicons meant and how they provoked actions that includes identity construction.

The next point is how we incorporate reflexive acts in our research practices and how we manage our reflexivity in our research practices. In what follows, I particularly focused on certain mediational tools to manage researcher's reflexivity. These tools can be largely grouped from theoretical, cognitive or practical perspectives (Mynard, 2012). Theoretical tools refer to theories and framework that researchers can draw on to examine the "process, context and outcomes of the research and interrogates the construction of knowledge" (Finlay, 2012, p. 317). Finlay's 'five critical lenses' mentioned earlier could be one example. Cognitive tools are items such as journals, subjective statements, notes used to stimulate cognitive and metacognitive process of the researcher's reflexivity. Practical tools include practices that facilitate the managing of the researcher's reflexivity; storing one's reflexive comments using Moodle platforms could be one example. My reflections that consisted of my thoughts recorded in my journal writings were revisited with data that emerged from the analytical model adding another dialogic dimension in relation to other data sets that were demonstrated in the form of 'reflexive vignettes' (RV). This extra step was not only effective in locating my subjectivity, but also enabled me to consider different aspects of myself (e.g. emotions, identities, positions, roles as well as my beliefs, assumptions, etc.), and evaluate the impact they could potentially have on the entire research. Such a 'reflexive space' also gave me the opportunity time to carefully monitor how and in which ways our beliefs and biases is crucial to the understanding the self in the creation of knowledge. The following are from my narrative work: an example from my research journal and reflexive note in verbatim of an interview with Maki to illustrate the role of the researcher and their participants in the process of analysis and presentation, and how emotions are implicated in the process. This following example highlights the reflexive process more at the analysis stage rather than, for instance, data collection phase such as sampling (Miyahara, forthcoming 2020).

\section{An Example: Stories of Maki's English Learning Trajectory}

\section{Maki's view towards English and English Learning}

The following interview extracts sketches Maki's views towards English and learning English. Materials directly relevant to emotions is underlined for clarity in each extract. 
Sense of enjoyment, fun, hope, desire, and to be 'cool' (Maher, 2005) are common positive emotions that were manifested clearly in these extracts.

\section{Excerpt 1}

... we (referring to Maki and her mother) would watch TV dramas like Full House or Friends. They were easy to listen to and you could usually figure out the story. The best part is that you don't necessarily have to fully understand the language. I remember my mother encouraging me to watch them without the subtitles. I think it helped me to improve my listening skills. I enjoyed them. I thought English was fun and hoped, someday, I would be able to communicate in English freely. It would be sort of 'cool' to be able to speak English like that in Japan.

Maki had a very positive view towards English and English language learning at this point of her life, namely, her school days at elementary school in Japan. At lower and upper middle school level, although she found English classroom 'boring', she nevertheless enjoyed learning English outside of the school.

\section{Excerpt 2}

English lessons were fun and interesting at these schools (referring to English conversational classes outside of the school). Of course, at that time, the lessons were mainly singing songs and playing games, but I felt that I was using English, English was real because I could talk to the native English speakers.

English at school was merely another school subject, once outside the school premises Maki had abundant opportunities to use colloquial English with 'native speakers' of English. It is interesting that she points out that classes at her English conversational school were 'mainly singing songs and playing games, but 'she felt that she was using English in a 'real' in an interactive way. English language teaching in Japan does not only occur in formal education contexts but more so in the private sector of many English language conversations schools. The general sentiment towards English in Japan regarding this formal and informal learning is that in the former, learning English is considered to be skill based and exam oriented, but in the latter, English is brought to 'life' through interactive teaching approaches, and is therefore, more attuned to the 'real' world. 
A significant shift in her views of English and learning English came about when Maki entered high school (one affiliated with the research site), adjacent to the university. This school is well known in Japan for its contributions to returnee education. For students whose parents live abroad, the school has dormitory facilities. Since Maki's mother had to live in Senegal for her research (by this time, her parents were divorced, and her mother was a researcher at a Japanese nursing college). Maki enjoyed her school life at this high school immensely.

\section{Excerpt 3}

There were many outspoken people, especially the returnees. I really enjoyed talking to them in English. I was delighted when they complimented me on my pronunciation... Some people told me that I would probably start hating English surrounded by fluent English speakers, but, it was the opposite. I became more interested and enthusiastic about learning English.

It is useful to provide a brief account of the returnees and how they are portrayed as Maki makes repeated reference to them. Returnees are mainly sons and daughters of Japanese governmental officials and business people who have lived abroad for a certain period of time during their childhood and adolescence before returning to Japan (Block, 2006b; Kanno, 2003). Educated abroad during their formative years, many returnees find it difficult to readjust to Japanese cultural norms, and encounter problems related to different cultural values and expectations (e.g. Block, 2006b; Kanno, 2003; Macdonald \& Kowatari, 1995; Yashiro, 1995) upon their return to Japan. Furthermore, returnees occupy an ambivalent position in Japanese society (Kanno, 2000, 2003). On the one hand, they are regarded as 'misfits' of Japanese society; however, on the other hand, they are deemed as a valuable societal resource because of their proficiency in a foreign language (mainly English). For the last few decades or so, however, the public has characterized the returnees more positively, and as a result, there is a strong 'akogare' (desire) towards these children and their supposedly international expertise. Maki was no exception to this trend. The returnees symbolized, a perfect model of an English speaking self as they expressed their opinions freely in both Japanese and English. Inspired by them, Maki had a strong desire to gain fluency in English. 


\section{Excerpt 4}

I have a strong desire for English, and the returnees. I see them talk in English like native speakers on the trains and in towns. I tried to mimic their pronunciation. They are 'cool'.

Maki's emotional disposition of desire and the coolness of been able to use English like the returnees is often illustrated in her interview extracts. As part of Maki's strong desire to be like the returnees is also exemplified in her behavior to mimic them by following their fashion and music. In order to align herself with musical tastes, Maki remembers how she started to listen to Western rock and pop, whereas previously she would have listened to Japanese pop music. She would frequently find herself looking up the meaning to the lyrics to keep up with their conversations.

\section{Excerpt 5}

I joined the dance club where I could meet up with the returnees. I downloaded many songs from the internet and checked the lyrics so that I could follow what they were talking about. And it was helpful in increasing my vocabulary! Plus good for improving my listening skills, I think... I wanted to become like them - the kikokusei (returnees).

I was able to identify emotional expressions such as Maki's desire (Piller \& Takahashi, 2006) towards the returnees and her desire to become a part of the returnee's community because of my returnee experiences as can be observed from my journal entries during this period of interviews with Maki as follows:

From my research journal \# 9, May MM, 20XX

Maki seemed particularly interested in my experiences as a 'returnee'. She appeared to have an akogare (desire) towards returnees. I spoke to her about the negativity, so to speak, associated with the term, a topic that is not openly discussed. She was definitely very intrigued by it. This helps to facilitate our discussions about her images of an ideal English speaker, and how she has (and also is) striving towards it. She clearly makes the distinction between herself as an English-learner and English-user. 
As most of my participants have expressed at one time or another, they differentiate between their identity as a learner and user (although they do not use these terms). Studying for term-end exams or college entrance exams mean they see themselves as English-learners; contrastively, picturing themselves as English-users means that they are able to see themselves as using English with their peers, teachers, returnees, overseas students on campus, etc. Such a desire or, if you want, imagination, to become English-users prompted me to think about their idealized selves, especially, Dörnyei's notion of Ideal L2 self.

From my corresponding RV for the above journal entry:

Had I taken advantage of my experiences as a returnee? It was interesting talking to her about the returnees. I could picture exactly what they were feeling and thinking. Maki said she would sometimes listen to American teen music; although she herself preferred J-pop. I remember some of my friends took similar actions when they wanted to establish friendship with me. Although Maki did not explain her actions, I could guess...... but in this case, should I have asked Maki her reasons? Am I assuming things here?

On the other hand, frustration or struggles was the most common 'negative' emotions observed from Maki's interview extracts. For example,

\section{Excerpt 6}

I don't remember much since I was only two years old, but it was a time of fun and full of excitement. Although I have no experience of going to schools overseas other than this, I have always envied people who can live abroad and attend schools there. As far as I am concerned, living only for two or three years when I was little does not make me a returnee.

Maki's case is interesting in terms of how she herself conceptualizes returnees. At the age of two, Maki's family moved to Bangladesh, where she received her pre-school education at an international school. Coming back to Japan a couple of years later when she was four years old, Maki does not consider herself a returnee. We can observe Maki's struggle and frustration from this excerpt. There appears to be a discrepancy in how Maki regards herself as a returnee and how she is positioned by others. She regards herself to be on 
the peripheral in terms of the community of returnees, so to speak; but to the general public, Maki is a returnee. I can keenly resonate with Maki since I have noticed similar frustration that some returnees experience upon their return to Japan. There is a 'division' among the returnees themselves as to who the 'legitimate' returnees are. Maki who has spent only two years at a pre-school in Bangladesh may not be considered a returnee compared to returnees who have lived overseas for an extended period time. The point is that I could identify the issues at stake here for Maki coming from a returnee background myself in terms of at least two junctures: First, the discussion of 'returnee' which enabled Maki to consciously distinguish between language learner and language user was a 'notion' that co-constructed between the researcher and the participant. Secondly, researcher/participant experiences and emotions as well as the identities that emerged from such emotions in the process of analyzing the data, my experience as a 'returnee' at this institute allowed me to bring to the surface, and offer explanations for, phenomena that could have otherwise been difficult. This 'shared experience' (Berger, 2015) provided me with the insights to sensitize myself to certain dimensions of the phenomena under study that probably an outsider would have overlooked. However, the insider position required me to be extremely watchful to maintain the 'distance' (or position) between myself as a 'researcher' and a member of this research context. Furthermore, my position enabled me to obtain deeper insights into the narratives of my participants because I could operate in both worlds. However, because of this, it was more important for me to maintain an awareness of the effects that my position including the emotions it evoked (or vice versa) might have had throughout the analysis (and, for that matter, the entire research process). Reflexivity has a critical role to play in such research context.

\section{Summary and Some Thoughts for the Future}

As interest in studies of emotions in language learning research increases, the area diversifies thematically, theoretically and methodologically. Recent studies have demonstrated the limitations of traditional approaches and the need for methodological rethinking of language learning process in order to pursue the complex and elusive nature of emotions. I have made attempts to illustrate the impact of my own experiences and emotions on data interpretation and emphasize that the inward reflexive look onto the research process helps to illuminate deeper understandings of how emotions functions to reflect the social phenomena at hand. 
If studies on emotions are fundamentally interpretative and subjective, the role of the researcher and the participants as well as the relationship between the two parties becomes even more relevant. In this kind of relationship, how a researcher's involvement influences and informs the research at all stages of the research process in an important methodological consideration that requires a careful reflexivity on the part of the researcher. Although, the issue of researcher reflexivity or the understanding that researchers' involvement could change the object of the study dates back even to the age of Labov (1972), the main question is 'how' and in what ways? I have attempted to address this matter through my research experiences that involved emotions and researcher/participant identities. Whilst I recognize the value of attempting to acknowledge one's own identities, bias, and ideas, I must admit, it was, and still is, to a certain extent, struggle. On reflection, one of my main struggles to write myself (researcher's voice) into the study is related to my often-overlapping roles and identities as a practitioner, researcher, which are combined with the experiences I shared with my participants that made it difficult for me to reflect critically at certain stages of the research process. Another was the ever-evolving nature of researcher's identities and the transformative nature of reflexivity. Going back to my original data and dwelling on my reflexive notes to write up this paper, I noticed that sometimes my interpretations of a certain excerpt of the transcript had undergone some changes. Although this paper has focused on the influence the researcher has on the research, there is also another dimension to reflexivity: that is, the influence of the research on the researcher (Edge, 2011). Many reasons could be attributed to the phenomena. But this would make sense if we consider the reflexivity as comprised of two facets that moves in a "hermeneutic cycle of mutually- shaping change as the researcher constructs the research, works to see how his/her subjectivity influences it, pursues research goals, and works to see how s/he is (being) influenced, in turn, by these processes and outcomes" (Edge, 2011, p. 37). Reflexivity can thus be both developmental and transformative, but we still need to explore how and in what ways these two dimensions intertwine with each other, the extent to which emotions plays in this complex endeavor. One possibility could be to investigate the collaborative nature of reflexivity to advance our understanding of the notion of researcher's reflexivity. Drawing on reflexivity as comprised of a social as well as an individual dimension, although the mediational tools suggested in this paper are based on the researchers' inner dialogue with themselves that are situated in a certain context, sharing these internal dialogues in collaboration with other researchers could contribute in fostering and developing researcher's reflexivity. Such attempts would lead to a broadening as well as a deepening of our understanding of the interactive, dynamic, and 
multidimensionality of reflexivity in narrative studies, and, concomitantly, qualitative research in general. Hopefully, this paper has raised enough questions that could serve as a starting point to make further inquiries for research that involves emotions in language learning research.

\section{References}

Arnold, J. (1999). (Ed.). Affect in language learning. Cambridge, UK: Cambridge University Press.

Benesch, S. (2012). Considering emotions in critical English language teaching. New York, NY: Routledge.

Berger, R. (2015). Now I see it, now I don't: Researcher's position and reflexivity in qualitative research. Qualitative Research, 15(2), 219-234. doi:10.1177/1468794112468475

Blaxter, L., Hughes, C., \& Tight, M. (2001). How to research (2 ${ }^{\text {nd }}$ ed.). Milton Keynes, UK: Open University Press

Block, D. (2003). The social turn in second language acquisition. Edinburgh, UK: Edinburgh University

Block, D. (2006a). Identity in applied linguistics. Where are we? In T. Omoniyi \& G. White (Eds.), The sociolinguistics of identity (pp. 34-49). London, UK: Continuum.

Block, D. (2006b). Multilingual identities in a global city: London stories. Baskingstoke, UK: Palgrave Macmillan.

Block, D. (2007). Second language identities. London, UK: Continuum.

Block, D. (2008). Narrative, identity and interviews: a personal reflection on key constructs and analytical practices. In M. Solly, M. Conoscenti \& S. Campagna (Eds.), Researching language in education: Verbal/visual narrative texts (pp. 25-51). Berlin, Germany: Peter Lang

Bruner, J. (1990). Acts of meaning. Cambridge, MA: Harvard University Press.

Canagarajah, S. (1996). From critical research practice to critical research reporting. TESOL Quarterly, 30(2), 321-331. doi:10.2307/3588146

Clandinin, D. J. (2007). Handbook of narrative inquiry. Thousand Oaks, CA: Sage.

Clandinin, D. J., \& Connelly, E. M. (2000). Narrative inquiry: Experience and story in qualitative research. San Francisco, CA: Jossey-Bass. 
Csillagh, V. (2015). Global trends and local realities: Lessons about economic benefits, selves and identity from a Swiss context. Studies in Second Language Learning and Teaching, 5(3), 431-453. doi:10.14746/ssllt.2015.5.3.5

De Costa, P. I. (2015). Reenvisioning language anxiety in the globalized classroom through a social imaginary lens. Language Learning 65(3), 504-532. doi:10.1111/lang.12121

Dewaele, J. M. (2015). On emotions in foreign language learning and use. The Language Teacher, 39(3), 13-15. Retrieved from http://jalt-publications.org/sites/default/files/pdfarticle/39.3tlt-art3.pdf

Dewaele, J. M., \& Li, C. (2018). Emotions in second language acquisition. Studies in Second Language Learning and Teaching, 8(1). 15-19. doi:10.14746/ssllt.2018.8.1.1

Dewaele, J. M., Mercer, S., \& Gkonou, C. (2018). Do ESL/EFL teachers' emotional intelligence, teaching experience, proficiency and gender, affect their classroom practice? In J. de D. Martinez Agudo (Ed.), Emotions in second language teaching (pp. 125-141). Berlin, Germany: Springer.

Doyle, S. (2013). Reflexivity and the capacity to think. Qualitative Health Research, 23(2), 248-255. doi:10.1177/1049732312467854

Dörnyei, Z. (2009). The L2 motivational self system. In Z. Dörnyei \& E. Ushioda (Eds.), Motivation, language identity and the L2 self. New York, NY: Multilingual Matters.

Edge, J. (2011). The reflexive teacher educator in TESOL: Roots and wings. New York, NY: Routledge

Frederickson, B. L. (2001). The role of positive emotions in positive psychology: The broaden and build theory of positive emotions. American Psychologist, 56(3), 218226. doi:10.1037/0003-066x.56.3.218

Finlay, L. (2012). Five lenses for the reflexive interviewer. In J. Gubrium, J. Holstein, A. Marvasti \& K. McKinney (Eds.), The SAGE handbook of interview research: The complexity of the craft (pp. 317-332). Thousand Oaks, CA: Sage.

Forgas, J. (2000). The role of affect in social cognition. In J. Forgas (Ed.), Feeling and thinking: the role of affect in social cognition (pp. 1-28). New York, NY: Cambridge University Press.

Frost, N. 2011. Qualitative research methods in psychology. London, UK: Open University Press.

Garret, P., \& Young, R. (2009). Theorizing affect in foreign language learning: Analysis of one learner's responses to communicative Portuguese course. Modern Language Journal, 93, 209-226. doi:10.1111/j.1540-4781.2009.00857.x

Gass, S., \& Selinker, L. (2008). Second language acquisition. An introductory course $\left(3^{\text {rd }}\right.$ edition). New York, NY: Routledge. 
Gkonou, C., \& Miller, E.R. (2017). Caring and emotional labour: Language teachers' engagement with anxious learners in private language school classrooms. Language Teaching Research 21(1), 1-16. doi: 10.1177/1362168817728739

Gubrium, J. F., \& Holstein, J. A. (2002). Handbook of interview research: Context and method. London, UK: Sage.

Hertz, R. (Ed.) (1997). Reflexivity \& voice. Thousand Oaks, CA: Sage

Horwitz, E. K. (2001). Language anxiety and achievement. Annual Review of Applied Linguistics, 21, 112-126. doi:10.1017/s0267190501000071

Kanno, Y. (2000). Bilingualism and identity: The stories of Japanese returnees. International Journal of Bilingual Education and Bilingualism 3(1), 1-17. doi:10.1080/13670050008667697

Kanno, Y. (2003). Negotiating bilingual and bicultural identities: Japanese returnees betwixt two worlds. Mahwah, NJ: Lawrence Erlbaum.

Kramsch, C. (2003a). Metaphor and the subjective construction of beliefs. In P. Kalaja \& A.M. Ferreira Barcelos (Eds.), Beliefs about SLA: New research approaches (pp. 109-128). Dordecht, The Netherlands: Kluwer

Kramsch, C. (2003b). The multilingual subject. In I. de Floro-Hansen \& A. Hu (Eds.), Plurilingualitat und Identitat. Zur Selbstund Fremdwahrnehmung mehrsprachiger (pp. 107-110). Tubingen, Germany: Stauffenburg

Labov, W. (1972). Language in the inner city: Studies in the black English vernacular. Philadelphia, PA: University of Pennsylvania.

Lei, Q. (2007). EFL teachers' factors and students' affect. US-China Education Review, 4(3), 60-67. Retrieved from https://files.eric.ed.gov/fulltext/ED497391.pdf

Maher, J. (2005). Metroethnicity, language, and the principle of cool. International Journal of the Sociology of Language, 175-176, 83-102. doi:10.1515/ijs1.2005.2005.175176.83

Mann, S. (2011). A critical review of qualitative interview in applied linguistics. Applied Linguistics, 32(1), 6-24. doi:10.1093/applin/amq043

Mann, S., \& Walsh, S. (2017) Reflective practice in English language teaching: ResearchBased principles and practices. London, UK: Routledge

MacIntyre, P. C. (2002). Motivation, anxiety, and emotion in second language acquisition. In P. Robinson (Ed.), Individual differences and instructed language learning (pp. 4568). Amsterdam, The Netherlands: John Benjamins.

MacIntyre, P. C., \& Gregersen, T. (2012). Affect: The role of language anxiety and other emotions in language learning. In S. Mercer, S. Ryan, \& M. Willimas (Eds.), 
Language learning psychology: Research, theory and pedagogy (pp. 102-118). Basingstoke, UK: Palgrave.

Martinez Agudo, J. de D. (Ed.) (2017). Emotions in second language teaching. Berlin, Germany: Springer

Mynard. J. (2012). A suggested model for advising in language learning. In J. Mynard \& L. Carson (Eds). Advising in language learning: Dialogue, tools and context (pp. 2638). Harlow, UK: Pearson.

McKinley, J., \& Rose, H. (2017). Editorial introduction. In J. McKinley \& H. Rose (Eds.), Doing research in applied linguistics (pp. 3-14). Oxford, UK: Routledge.

Mishler, E. (1986). Research interviewing: Context and narrative. Cambridge, MA: Harvard University Press.

Miyahara, M. (2015). Emerging self-identities and emotions in foreign language learning: A narrative oriented approach. Bristol, UK: Multilingual Matters.

Miyahara, M. (2017). Narratives in language learning research: Developing a reflexive framework. Educational Studies, 59, 87-104.

Miyahara, M. (forthcoming 2020). Sampling: Problematizing the issue. In J. McKinley \& H. Rose (Eds.), Routledge handbook of research methods in applied linguistics. London, UK: Routledge.

Nagar, R., \& Geiger, S. (2007). Reflexivity and positionality in feminist fieldwork revisited. In A. Tickell, E. Sheppard, J. Peck \& T. Barnes (Eds.), Politics and practice in economic geography. London, UK: Sage.

Norton, B. (2013). Identity and language learning: Extending the conversation ( $2^{\text {nd }}$ edition) Bristol, UK: Multilingual Matters.

Oxford, R. (2015). Emotions as the amplifier and the primary motive: Some theories of emotion with relevance to language learning. Studies in Second Language Learning and Teaching, 5(3), 371-393.

Piller, I., \& Takahashi, K. (2006). A passion for English: Desire and the language market. In A. Pavlenko (Ed.), Bilingual minds: Emotional experience, expression, and representation (pp. 59-830). Clevedon, UK: Multilingual Matters.

Preece, S. (2016). (Ed). The Routledge handbook of language and identity. London, UK: Routledge.

Prior, M. (2016). Emotion and discourses in L2 narrative research. Bristol, UK: Multilingual Matters.

Pavlenko, A. (2005). Emotions and multilingualism. Cambridge, UK: Cambridge University Press. 
Presser, L. (2005). Negotiating power and narrative in research. Implications for feminist methodology. Sings: Journal of Women and Culture and Society, 30(4), 2067-2090. doi:10.1086/428424

Riessman, C. (2008). Narrative methods for human sciences. Thousand Oaks, CA: Sage.

Riessman, D. (2012). Analysis of personal narratives. In J. Gubrium, J. A. Holstein, A. B. Marvasti, K. D. McKinney (Eds.), The SAGE handbook of interview research: The complexity of the craft (2 ${ }^{\text {nd }}$ Edition) (pp. 367-380). New York, NY: Sage

Roulston, K. (2010a). Considering quality in qualitative interview. Qualitative Research, 10(2), 199-228. doi:10.1177/1468794109356739

Roulston, K. (2010b). Reflective researcher: Learning to interview in the social sciences. Thousand Oaks, CA: SAGE

Sarbin, T. R. (2001). Embodiment and the narrative structure of emotional life. Narrative Inquiry, 11(1), 217-225. doi:10.1075/ni.11.1.09sar

Schunk, D. H., Pintrich, P. R., \& Meece, J. L. (2008). Motivation in education: Theory, research, and applications (3rd ed.). Upper Saddle River, NJ: Merrill/Prentice Hall.

Swain, M. (2013). The inseparability of cognition and emotion in second language learning. Language Teaching, 46(2), 195-207. doi:10.1017/s0261444811000486

Zembylas, M. (2003). Emotions and teacher identity: A poststructural perspective. Teachers and Teaching: Theory and Practice, 9(3), 213-238. doi:10.1080/13540600309378 